\title{
Spatial variation of benthic microbial production and hydrolytic enzymatic activity down the continental slope of the Celtic Sea
}

\author{
Knut Poremba ${ }^{1}$, Hans-Georg Hoppe ${ }^{2}$ \\ ${ }^{1}$ Forschungs- und Technologiezentrum Westküste, Universität Kiel, Hafentörn, D-25761 Büsum, Germany \\ ${ }^{2}$ Institut für Meereskunde an der Universität Kiel, Düsternbrooker Weg 20, D-24105 Kiel, Germany
}

\begin{abstract}
Microbial activity was determined in the upper $10 \mathrm{~cm}$ of sediments and in bottom water of the European continental shelf margin in the Celtic Sea (Goban Spur: $48^{\circ}$ to $50^{\circ} \mathrm{N}, 10^{\circ}$ to $14^{\circ} \mathrm{W} ; 135$ to $1680 \mathrm{~m}$ deep). Assays used were the measurement of bacterial abundance (determined by epifluorescence microscopy), bacterial production (by thymidine incorporation) and hydrolytic enzymatic activity (by cleavage of fluorogenic model substrates). The highest activity was always measured in the top horizon (upper $1 \mathrm{~cm}$ layer) of the sediment, while in the water overlying the sediment about 1 to $5 \%$ of the sediment's surface value was found. The highest hydrolytic activity was mostly achieved by protease followed by esterase, chitinase, $\beta$-glucosidase, and $\alpha$-glucosidase. Most tested activities in the sediment declined with increasing depth down the continental slope, but the steepness of decline was different for the various substrates. While protease and chitinase showed nearly no depth relation, there was a strong response recorded for the 2 glycosidases. This leads to shifting ratios between the activities, indicating that not only microbial growth and general decomposition activity but also the type of reactions involved in the decomposition processes change with depth. Our observations may reflect differences in the microbial population structure as well as availability and biodegradability of specific compounds at the sea floor, as a result of successive losses of easily degradable substances from particulate organic matter on its way from the epipelagic zone to the sediment.
\end{abstract}

KEY WORDS: Bacteria · Sediment · Hydrolytic enzymes $\cdot$ Microbial production · Ocean margin

\section{INTRODUCTION}

It is now generally recognized by marine biologists that heterotrophic microorganisms comprise a large fraction of the living biomass in the illuminated surface layer of the ocean (about 10 to $30 \%$ of the phytoplankton biomass) (Billen et al. 1990, Ducklow et al. 1993, Lochte et al. 1993). They are responsible for the utilization of the extensive pool of dissolved organic carbon (DOC), thus making it available for the food web of this layer (Williams 1981, Ducklow 1983). The importance of bacteria for substrate conversion is assumed to be even greater in the environment below the euphotic zone (Hoppe et al. 1993), where, for example, in deepsea sediments bacteria account for about $90 \%$ of the total biomass (Pfannkuche 1993). The conversion of organic material into bacterial biomass is the initial step of the detritus food web and a key factor for life in the deeper ocean (Meyer-Reil 1990, Hoppe 1991). However, due to the lack of organic nutrients, the deep ocean is characterized by low productivity rates and biomasses. Except at special locations, like hydrothermal vents, where chemoautotrophy can fuel extraordinary food webs, the nutrition of heterotrophic life in the deep ocean depends on the remains of particulate organic matter produced in the euphotic zone (Gage \& Tyler 1991).

Several recent investigations indicate that there are seasonal pulses of sedimented particulate organic matter into the deep sea (Deuser \& Ross 1980, Deuser et al. 1981, Honjo 1982, Billett et al. 1983, Lampitt 1985, Rice et al. 1986, Thiel et al. 1988/89), which stimulate the activity of small organisms like microflagellates (Turley et al. 1988), foraminifera (Gooday 1988, Altenbach 
1992), and bacteria (Turley \& Lochte 1990, Meyer-Reil $\&$ Köster 1992, Poremba 1994) at the sea floor. The time lag for the microbial response to pulses of nutrient supply seems to be occasionally only $\leq 1$. wk (Graf 1989, Boetius \& Lochte 1994). This leads to the assumption that processes of deposition and degradation of organic material at the deep-sea floor are obviously coupled with processes of primary production in the epipelagic zone. In turn, microbial activity in the sediment possibly reflects the nutritional state of the deepsea floor. The degree of this coupling, however, depends essentially on decomposition processes of particulate organic material (POM) during sedimentation, which is mainly a function of water depth. As shown by sediment trap measurements, the concentration of sinking POM decreases with ocean depth (e.g. Knauer \& Martin 1981, Suess 1988). This has been mainly attributed to bacterial degradation (Smith et al. 1992). It could be demonstrated that in the open ocean only about $10 \%$ of the primary production (PP) descends down to $150 \mathrm{~m}$ (Angel 1984), and again about $10 \%$ of the remaining material reaches the deep-sea bottom at 4 to $5 \mathrm{~km}$ depth (Wefer 1989). On the other hand, at shallow coastal stations about $50 \%$ of the PP may reach the sea floor (Walsh et al. 1981). The importance of lateral transport by advective water currents increases with proximity to the continental shelf (Rowe \& Staresinic 1979).

Depth relation of organic matter and bacterial activity in deep sediments also depends on physical characteristics and biological activity in the water column as well as on physical properties of the investigated sediments. Therefore, microbial activity in sediments across the continental shelf cannot be predicted exclusively on the basis of increasing water depth, but it has to be measured in any particular case. This subject was investigated on a RV 'Valdivia' cruise of the European OMEX (Ocean Margin Exchange) campaign along the continental margin of the Celtic Sea in June/July 1993. Our interest focussed on changes of bacterial growth and hydrolytic enzyme activities down the slope with special emphasis on shifts of the relations between different enzyme activities. A similar approach has been reported by Alongi (1990), who found a decline in bacterial production in the 0 to $0.5 \mathrm{~cm}$ surface layer of deep-sea sediments of the tropical Solomon and Coral Seas (down to $4350 \mathrm{~m}$ depth). In contrast to the investigation of Alongi, we took samples down to $10 \mathrm{~cm}$ sediment depth, and we measured not only bacterial production but also the rates of 5 hydrolytic enzymes.

Our investigation on changes of microbial activity along the continental slope cannot take into account all the factors determining the deposition and concentration of organic matter at the sea floor (e.g. terrestrial or advective inputs, productivity of the surface water layer, bottom currents), but it presents detailed information on changes of bacterial decomposition activities in the sediment as they are influenced by water depth and other related factors.

\section{MATERIAL AND METHODS}

Sampling site and ship-board handling. During the RV 'Valdivia' cruise 137 (22 June to 18 July 1993) sediment samples were taken on a transect across Goban Spur in depths between 135 and $1680 \mathrm{~m}$. Goban Spur is situated at the continental shelf edge in the Celtic Sea, NE Atlantic $\left(48^{\circ}\right.$ to $50^{\circ} \mathrm{N}, 10^{\circ}$ to $\left.14^{\circ} \mathrm{W}\right)$. The samples were taken by a multiple corer (Barnett et al. 1984) equipped with 12 plastic tubes $(5.5 \mathrm{~cm}$ diameter, $50 \mathrm{~cm}$ length), which allowed sampling of relatively undisturbed cores.

On board, the tubes (sediment with overlying water) were immediately transferred to a cooled container in order to avoid temperature changes in the samples. Experiments were made under specific pressure conditions (repressurization, see below) and at in situ temperature (details are shown in Table 1).

Bacterial counts and biomass measurements. Samples of the water overlying the sediment in the multiple corer tubes (the sediment-contact water, SCW) were

Table 1. Locations and depth of the stations, Goban Spur at the continental shelf edge in the Celtic Sea

\begin{tabular}{|c|c|c|c|c|c|c|}
\hline Stn & $\begin{array}{c}\text { Date } \\
\text { (1993) }\end{array}$ & Latitude $(\mathrm{N})$ & Longitude (W) & $\begin{array}{l}\text { Depth } \\
(\mathrm{m})\end{array}$ & $\begin{array}{c}\text { Temperature during } \\
\text { experiment }\left({ }^{\circ} \mathrm{C}\right)\end{array}$ & $\begin{array}{l}\text { Type of } \\
\text { experiment }\end{array}$ \\
\hline 3 & 29 Jun & $49^{\circ} 22.49^{\prime}$ & $12^{\circ} 32.08^{\circ}$ & 1252 & 8 & TdR-uptake \\
\hline 4 & 29 Jun & $49^{\circ} 12.33^{\prime}$ & $12^{\circ} 54.36^{\prime}$ & 1680 & 6 & Enzymes \\
\hline 5 & $03 \mathrm{JuI}$ & $49^{\circ} 12.45^{\prime}$ & $12^{\circ} 53.75^{\prime}$ & 1630 & 6 & TdR-uptake \\
\hline 6 & $03 \mathrm{Jul}$ & $49^{\circ} 20.21^{\prime}$ & $12^{\circ} 29.92^{\prime}$ & 1216 & 8 & Enzymes \\
\hline 7 & $04 \mathrm{Jul}$ & $49^{\circ} 29.88^{\prime}$ & $11^{\circ} 28.66^{\prime}$ & 571 & 10 & TdR-uptake \\
\hline 8 & $04 \mathrm{Jul}$ & $49^{\circ} 27.29^{\prime}$ & $11^{\circ} 29.07^{\prime}$ & 580 & 10 & Enzymes \\
\hline 9 & $05 \mathrm{Jul}$ & $49^{\circ} 29.55^{\prime}$ & $10^{\circ} 29.56^{\prime}$ & 135 & 11 & TdR-uptake \\
\hline 10 & $05 \mathrm{Jul}$ & $49^{\circ} 28.20^{\prime}$ & $10^{\circ} 31.35^{\prime}$ & 135 & 11 & Enzymes \\
\hline
\end{tabular}


taken, fixed with formaldehyde ( $4 \%$ final concentration), and stored cool and dark for later analysis. Samples from the sediment cores (subcores) were taken by syringes; subcores were shock-frozen at $-70^{\circ} \mathrm{C}$ and sectioned in $1 \mathrm{~cm}$ horizons. Each horizon was diluted 10 -fold in pre-filtered $(0.2 \mu \mathrm{m})$ sea water supplemented with formaldehyde (4\% final concentration) and stored. In the laboratory, the sediment samples were diluted 10 -fold with filtered distilled water, ultrasonicated for $5 \mathrm{~s}$ to separate bacteria from sediment particles, and diluted a further 100 -fold, giving a final dilution of $10^{-4}$. An appropriate volume of 2 to $5 \mathrm{ml}$ was filtered onto a $0.2 \mu \mathrm{m}$ Nuclepore polycarbonate membrane, stained for $3 \mathrm{~min}$ with $0.1 \%$ acridine orange (Zimmermann \& Meyer-Reil 1974), washed with citrate buffer $(0.056 \mathrm{M} \mathrm{Na}$-citrate, $0.056 \mathrm{M} \mathrm{NaOH}, 0.044 \mathrm{M}$ $\mathrm{HCl}, \mathrm{pH} 4)$ and counted with an epifluorescence microscope. The bacterial biomass was calculated by measuring the cell volumes of 50 cells per sample using a graticule grid (New Porton, Tonbridge, UK), and by estimating their specific carbon content using the power function of Simon \& Azam (1989).

Measurement of thymidine incorporation. The incorporation of tritiated thymidine was measured according to the method of Moriarty (1990). For each experiment with sediment samples, the most undisturbed 3 of the 12 cores of the sampler were selected for the experiment. The 20 to $30 \mathrm{~cm}$ column of SCW in the tubes was collected. The cores were sectioned in $1 \mathrm{~cm}$ layers and from the 3 cores the $0-1,3-4$, and $9-10 \mathrm{~cm}$ horizons were pooled. Slurries were prepared by diluting the pooled samples 1:1 with sterilized deep-water. Aliquots of $10 \mathrm{ml}$ slurry or $50 \mathrm{ml} \mathrm{SCW}$ were pipetted into sterilized plastic bags and supplemented with [methyl- ${ }^{3} \mathrm{H}$ ]-thymine-desoxy-ribose (TdR, DuPont de Nemours, Germany; specific activity: $80 \mathrm{Ci}$ $\mathrm{mmol}^{-1}$ ). The final substrate concentrations in the bags were $25 \mathrm{nM}$ TdR in the slurries and $10 \mathrm{nM} \mathrm{TdR}$ in the SCW. Our concentrations of TdR used for the determination of bacterial production lie in the range of those applied in sediment by Meyer-Reil 1986 (15 nM) and Thorn \& Ventullo 1988 (125 nM). Some of the bags were kept at 1 atm in the dark; the others were incubated in pressure vessels under the in situ pressure conditions of the sample's origin. The pressurization/ depressurization rate was about $100 \mathrm{~atm} \mathrm{~min}^{-1}$. After $0,3,6,12$, and $24 \mathrm{~h}$ bags were removed. The incubation was stopped by injecting $500 \mu \mathrm{l}$ of $37 \%$ formaldehyde into the SCW bags or by resuspending triplicates of $3 \mathrm{ml}$ sediment slurry with $10 \mathrm{ml}$ EAT buffer $(80 \mathrm{ml}$ absolute ethanol, $20 \mathrm{ml}$ distilled water, $10 \mathrm{mg}$ thymidine), respectively. The fixed samples were stored for $\leq 7 \mathrm{~d}$ cool and dark

For the extraction of labelled particulate matter from the $\mathrm{SCW}$, the water samples were filtered on $0.2 \mu \mathrm{m}$
Nuclepore filters. After washing once with $10 \mathrm{ml}$ icecold prefiltered sea water, extraction with $10 \mathrm{ml}$ of $5 \%$ ice-cold trichloroacetic acid (TCA) for $5 \mathrm{~min}$, and 5 washings with $1 \mathrm{ml} \mathrm{TCA}$, the filters were transferred into a minivial. Scintillation cocktail $(5 \mathrm{ml}$, Lumagel, Baker Analyzed) was added and the radioactivity measured in a Beckmann liquid scintillation counter.

For extracting the sediment samples, the slurry/EAT. buffer mixtures were centrifuged $(5 \mathrm{~min}, 5530 \times \mathrm{g}$. $2^{\circ} \mathrm{C}$ ), and the supernatant was discarded. For removing carbonates, the sediment was resuspended in $10 \mathrm{ml}$ of $20 \%$ acetic acid and stored in the dark at $4^{\circ} \mathrm{C}$, until no more bubbles arose from the sediment (after approximately 1 to $2 \mathrm{~d}$ ). The slurry was centrifuged again, the supernatant discarded, and the sediment resuspended in $2 \mathrm{ml}$ EAT buffer. This mixture was filtered on a $0.2 \mu \mathrm{m}$ Nuclepore filter, and washed 4 times with $2 \mathrm{ml}$ TCA. The filter was put into a tube, supplemented with $2 \mathrm{ml}$ TCA containing $1 \mathrm{mM}$ unlabelled thymidine, and heated to $100^{\circ} \mathrm{C}$ for $30 \mathrm{~min}$. After cooling and centrifuging, $500 \mu \mathrm{l}$ supernatant was pipetted into a minivial, and after addition of scintillation cocktail the radioactivity was measured in a scintillation counter. For converting obtained cpm (counts per minute) to molar units, a calibration with known amounts of pure labelled thymidine was carried out. Tests for recovery efficiency of thymidine were not made because there are no generally accepted and reliable methods available. Using the same extraction procedure as was applied in our study, Alongi (1990) recovered $62 \pm 10 \%$ of DNA in deep-sea sediments of various types. Assuming a similar efficiency for the sediments studied here, our calculation would have underestimated the bacterial production by $38 \pm 10 \%$

Measurement of hydrolytic activities. Enzyme activities in deep-sea sediment down to $10 \mathrm{~cm}$ depth were measured by using analog substrates for protease (model substrate: L-leucine-7-amino-4-methylcoumarin; final test concentration: $1000 \mu \mathrm{M}$ ), esterase (fluoresceindiacetate; $100 \mu \mathrm{M}$ ), chitinase (4-methylumbelliferyl-N-acetyl- $\beta$-D-glucosamine; $100 \mu \mathrm{M}), \beta$-glucosidase (4-methylumbelliferyl- $\beta$-D-glucoside; $100 \mu \mathrm{M}$ ), and $\alpha$-glucosidase (4-methylumbelliferyl- $\alpha$-D-glucoside; $50 \mu \mathrm{M})$. Substrate concentrations were chosen according to experimentally verified substrate saturation levels. The sediment was sectioned in $1 \mathrm{~cm}$ horizons, and pooled samples from several cores were diluted 1:1 with sterilized deep-sea water. The slurries were pipetted into sterilized plastic bags, supplemented with substrates, and incubated at 1 atm under in situ temperature. Incubations were terminated after $0,2,4$, or $6 \mathrm{~h}$ by diluting a $1 \mathrm{ml}$ portion of slurry with $9 \mathrm{ml}$ sea water, and then centrifuged for $5 \mathrm{~min}$ at $5530 \times g$ and $2{ }^{\circ} \mathrm{C}$. For controlling abiotic cleavage of the substrates, additional series were run with auto- 
claved sediments. Fluorescence was determined with a Jasco FP-550 fluorometer calibrated with 7-amino-4methylcoumarin, fluorescein, and 4-methylumbelliferone. All assays were done in triplicate.

Calculation of activity rates. The time-dependent increase of incorporated labelled material or production of fluorescence in the samples was used for calculating TdR incorporation or hydrolytic activity, respectively, by linear regression. In order to relate measurements obtained from the slurries back to the undiluted sediment, dry weights of sediment and slurry were determined. Statistical analyses (standard deviation, time series regression, activity to ocean depth regression, and confidence level) were made with the regression tools of the Microsoft Lotus 1-2-3 programme.

TdR uptake was converted to cell production by estimating an efficiency of $1.1 \times 10^{18}$ cells $\mathrm{mol}^{-1} \mathrm{TdR}$. This conversion factor was determined for water samples (Riemann et al. 1987), and we also found a similar factor $\left(1.14 \times 10^{18}\right.$ cells $\left.\mathrm{mol}^{-1} \mathrm{TdR}\right)$ in SCW in the $4550 \mathrm{~m}$ deep NE Atlantic (Poremba et al. 1994). From this the bacterial $\mathrm{C}$ production was calculated using the mean $C$ content cell ${ }^{-1}$ of the sample calculated by the power function provided by Simon \& Azam (1989). Growth rate was calculated by dividing bacterial $\mathrm{C}$ production by bacterial biomass.

\section{RESULTS AND DISCUSSION}

Bacterial activity was studied in sediment cores along a transect across the Goban Spur shelf edge at depths from 135 to $1630 \mathrm{~m}$. It was the aim of our study to define quantitative and qualitative changes of bacterial activities in sediments as they are influenced by water depth, distance from land, and slope of the transect. With respect to nutrient supply of the sediment, increasing depth would mean longer sinking time of particles in the water column and thus probably more degradation and less input into the sediment (Suess 1988). Proximity to land could favour POC production at the surface and consequently the deposition of material. Lateral transport down the slope may lead to accumulation of organic matter at greater depth. Our results cannot distinguish between these factors but present the effect of combined factors on bacterial sediment activity.

The measurement of microbial activity in sediment samples is always problematic because the experimental design can easily lead to misinterpretations. For this study, we used sediment slurries, which avoids problems concerning the even distribution of the supplemented substrates in the sediment. The drawback of this method is that the original structure of the sediment is destroyed. In previous experiments we found that negative effects increased with dilution steps (Poremba et al. 1993). Therefore we tried to minimize the disturbance by using only 1:1 diluted (vol/vol) slurries of sediment. This might not be as appropriate as direct injection of tracer substrate into the cores, used by Meyer-Reil (1986). However, because fine structure and package of sediments along the transect differed considerably, it could be anticipated that diffusion of substrate would also be different when applying the injection technique. Therefore the preparation of slurries appeared to be the most promising technique for direct comparision of activity measurements. Slurries were prepared by pooling sediments from 3 selected multicorer tubes in order to avoid effects of patchiness. It was not the aim of our study to specify patchiness at sampling sites, but to show depth-dependent differences of their metabolic activity. In order to minimize effects of stimulation by added tracer substances, we incubated for relatively short periods of time (up to $6 \mathrm{~h}$ for enzyme activity, up to $24 \mathrm{~h}$ for thymidine incorporation). Further reductions of incubation times were not possible because of the low activity in the samples.

Bacterial biomass ranged from 1.4 to $8.1 \mathrm{ng} \mathrm{C} \mathrm{ml}^{-1}$ in the SCW and from 3.2 to $11.6 \mu \mathrm{g} \mathrm{C} \mathrm{ml}^{-1}$ in the sediments (Table 2). A significant shift of bacterial abundance corresponding to ocean depth was not found. This may be due to the high standard deviation (SD) typical for the microscopic direct counting of sediment bacteria (Meyer-Reil 1993; here SD accounted for 30 to $70 \%$ ). The decline of bacterial abundances across the slope was possibly too small to be detected with the direct counting method. However, our results are supported by observations of Alongi (1990), who also did not find a correlation between bacterial densities and ocean depth in the Solomon and Coral Seas, although his sediment stations extended over a wide depth range from 695 to $4350 \mathrm{~m}$.

The highest values of microbial growth activity were found mostly in the sediment's surface layer (Table 2). Bacterial production in the SCW accounted only for 1 to $4.8 \%$ of that in the top sediment horizon. Within the sediment core, activities slowly decreased. Standard deviations of activity measurements of different horizons (Table 2) suggest that there was only a significant decline between the $0-1 \mathrm{~cm}$ and $9-10 \mathrm{~cm}$ layer of the sediment. Comparing the specific growth rates of the different compartments, it is striking that these rates are much higher in the SCW than in the sediment, and that the ratio of the rates increases with ocean depth from 20 (135 m depth) to $200(1630 \mathrm{~m}$ ). This trend cannot be explained by a declining number of bacteria in the sediment, because there was none, 
Table 2. Estimates of bacterial densities, carbon production ( \pm SD) and specific growth rates in the sediment-contact water (SCW) and the sediment at Goban Spur

\begin{tabular}{|c|c|c|c|c|c|c|c|c|}
\hline Stn & $\begin{array}{l}\text { Depth } \\
\text { (m) }\end{array}$ & Compartment & $\begin{array}{c}\text { Total } \\
\text { bacterial } \\
\text { no. }\left(\mathrm{ml}^{-1}\right)\end{array}$ & $\begin{array}{c}\text { Bacterial } \\
\text { biomass } \\
\text { (ng C ml-1) }\end{array}$ & $\begin{array}{c}\text { Mean C } \\
\text { content } \\
\left(\text { fg } C \text { cell }{ }^{-1}\right)\end{array}$ & $\begin{array}{c}\mathrm{TdR} \\
\text { uptake rate }\left(\mathrm{r}^{2}\right) \\
\left.\text { (fmol } \mathrm{ml}^{-1} \mathrm{~h}^{-1}\right)\end{array}$ & $\begin{array}{c}\text { Bacterial } \\
\text { production } \\
\left(\mathrm{ng} C \mathrm{l}^{-1} \mathrm{~d}^{-1}\right)\end{array}$ & $\begin{array}{l}\text { Specific } \\
\text { growth } \\
\text { rate }^{b}\left(d^{-1}\right)\end{array}$ \\
\hline 9 & 135 & $\begin{array}{l}\text { SCW } \\
0-1 \mathrm{~cm} \text { horizon } \\
3-4 \mathrm{~cm} \text { horizon } \\
9-10 \mathrm{~cm} \text { horizon }\end{array}$ & $\begin{array}{l}5.88 \times 10^{5} \\
3.07 \times 10^{8} \\
2.20 \times 10^{8} \\
3.67 \times 10^{8}\end{array}$ & $\begin{array}{l}8.13 \\
4262 \\
3248 \\
5471\end{array}$ & $\begin{array}{l}13.8 \\
13.9 \\
14.8 \\
14.9\end{array}$ & $\begin{array}{r}0.59 \pm 0.08(0.880) \\
14.79 \pm 1.94(0.817) \\
11.00 \pm 0.48(0.976) \\
10.64 \pm 1.30(0.837)\end{array}$ & $\begin{array}{l}0.22 \pm 0.03 \\
5.43 \pm 0.71 \\
4.29 \pm 0.19 \\
4.18 \pm 0.51\end{array}$ & $\begin{array}{l}0.0271 \\
0.0013 \\
0.0013 \\
0.0008\end{array}$ \\
\hline 7 & 571 & $\begin{array}{l}\text { SCW } \\
0-1 \mathrm{~cm} \text { horizon } \\
3-4 \mathrm{~cm} \text { horizon } \\
9-10 \mathrm{~cm} \text { horizon }\end{array}$ & $\begin{array}{l}1.67 \times 10^{5} \\
5.35 \times 10^{8} \\
4.21 \times 10^{8} \\
3.01 \times 10^{8}\end{array}$ & $\begin{array}{l}2.35 \\
8275 \\
6672 \\
4621\end{array}$ & $\begin{array}{l}14.1 \\
15.1 \\
15.8 \\
15.3\end{array}$ & $\begin{array}{r}0.19 \pm 0.01(0.964) \\
11.55 \pm 5.06(0.634) \\
9.33 \pm 2.53(0.820) \\
1.18 \pm 1.16(0.255)\end{array}$ & $\begin{array}{l}0.07 \pm 0.01 \\
4.60 \pm 2.02 \\
3.89 \pm 1.06 \\
0.48 \pm 0.47\end{array}$ & $\begin{array}{l}0.0298 \\
0.0006 \\
0.0006 \\
0.0001\end{array}$ \\
\hline 6 & 1216 & $\begin{array}{l}\text { SCW } \\
0-1 \mathrm{~cm} \text { horizon } \\
3-4 \mathrm{~cm} \text { horizon } \\
9-10 \mathrm{~cm} \text { horizon }\end{array}$ & $\begin{array}{l}2.01 \times 10^{5} \\
8.13 \times 10^{8} \\
7.46 \times 10^{8} \\
4.45 \times 10^{8}\end{array}$ & $\begin{array}{c}3.47 \\
11608 \\
10391 \\
6059\end{array}$ & $\begin{array}{l}17.3 \\
14.3 \\
13.9 \\
13.6\end{array}$ & $\begin{array}{l}0.21 \pm 0.01(0.991) \\
4.39 \pm 2.76(0.458) \\
4.85 \pm 0.29(0.990) \\
0.64 \pm 0.12(0.908)\end{array}$ & $\begin{array}{l}0.10 \pm 0.01 \\
1.66 \pm 1.04 \\
1.78 \pm 0.11 \\
0.23 \pm 0.04\end{array}$ & $\begin{array}{l}0.0288 \\
0.0001 \\
0.0001 \\
0.0001^{c}\end{array}$ \\
\hline 5 & 1630 & $\begin{array}{l}\text { SCW } \\
0-1 \mathrm{~cm} \text { horizon } \\
3-4 \mathrm{~cm} \text { horizon } \\
9-10 \mathrm{~cm} \text { horizon }\end{array}$ & $\begin{array}{l}9.60 \times 10^{5} \\
6.55 \times 10^{8} \\
5.75 \times 10^{8} \\
3.74 \times 10^{8}\end{array}$ & $\begin{array}{l}1.37 \\
9443 \\
6996 \\
5799\end{array}$ & $\begin{array}{l}14.3 \\
14.4 \\
14.2 \\
15.5\end{array}$ & $\begin{array}{l}0.04 \pm 0.01(0.903) \\
3.96 \pm 1.41(0.724) \\
3.42 \pm 0.76(0.870) \\
0.93 \pm 0.18(0.900)\end{array}$ & $\begin{array}{l}0.02 \pm 0.01 \\
1.51 \pm 0.54 \\
1.28 \pm 0.28 \\
0.38 \pm 0.07\end{array}$ & $\begin{array}{l}0.0146 \\
0.0002 \\
0.0002 \\
0.0001\end{array}$ \\
\hline $\begin{array}{l}\text { cell } \\
{ }^{\mathrm{b}} \mu(\mathrm{c} \\
{ }^{\mathrm{c}} \mathrm{Rou}\end{array}$ & $\begin{array}{l}l^{-1} \text { of the } \\
\left.d^{-1}\right)=B c \\
\text { anded of }\end{array}$ & $\begin{array}{l}\text { mple using the } p \\
\text { rial production / } \mathrm{B} \\
\text { ten-thousandths }\end{array}$ & $\begin{array}{l}\text { er function } \\
\text { erial biom } \\
\text { ice }\end{array}$ & Simon \& & m (1989) & $\mathrm{d} / \mathrm{K}$ & f) $\mathrm{d}$ & 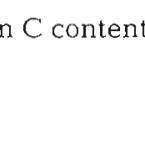 \\
\hline
\end{tabular}

but it may indicate that the fraction of growing bacteria in the sediment increases faster with increasing ocean depth than in the SCW.

Along the continental slope a clear relationship between ocean depth and TdR uptake rate, bacterial production as well as specific growth rate can be recognized (Table 2). The relationships between TdR uptake and depth are shown in Table 3.

Slopes of regression lines in sediment (between 0.000355 and 0.000666 ) are similar to that computed by Alongi (1990) for the relation between depth (695 to $4350 \mathrm{~m}$ ) and bacterial production $\left(\mu \mathrm{g} \mathrm{C} \mathrm{m} \mathrm{C}^{-2} \mathrm{~d}^{-1}\right)$ in the $0-0.5 \mathrm{~cm}$ horizon of sediments:

$\log$ Bacterial production $=-0.000537$ Depth +5.3 ;

$$
\mathrm{n}=8, \mathrm{r}^{2}=0.75
$$

Only 2 of our regressions are significant at the $95 \%$ confidence level. We are aware of the fact that many more investigations of this type are necessary to verify the obtained factors. It could turn out that continental slopes are individual with respect to their depth-dependent microbial activities in sediment. But it could also be that water depth per se compensates for biological and hydrographical characteristics of different slopes to a certain extent, which would result in a more uniform factor.
Comparisons of TdR uptake of incubations at $1 \mathrm{~atm}$ and at in situ pressure revealed in only 2 cases $(0-1 \mathrm{~cm}$ horizon of $\operatorname{Stn} 6$ and $9-10 \mathrm{~cm}$ horizon of Stn 7) significantly higher rates under in situ pressure conditions. Thus there was no indication of a barophilic response. We were surprised by these results, because previous experiments in sediment of the deep NE Atlantic $(4550 \mathrm{~m})$ had shown that bacterial assemblages can possess 2 to 8 times higher TdR uptake activity under in situ pressure conditions (Poremba et al. 1994). There are several possibilities for the interpretation of our present results, but it cannot yet be decided which is the most important one. (1) Absence of barophilic response could be a slope effect, because sediment at continental slopes may not be inhabited by a typical deep-sea bacterial community. (2) Sampled water

Table 3. Calculation of linear relations between TdR uptake and ocean depth $(\mathrm{n}=4)$. Activity in fmol $\mathrm{ml}^{-1} \mathrm{~h}^{-1}$; depth in $\mathrm{m}$

\begin{tabular}{|llc|}
\hline Compartment & Equation & $\begin{array}{l}\text { Regression } \\
\text { coefficient }\end{array}$ \\
\cline { 2 - 3 } SCW & $\log$ Activity $=-0.000648$ Depth -1.82 & $\mathrm{r}^{2}=0.797$ \\
$0-1 \mathrm{~cm}$ horizon & $\log$ Activity $=-0.000425$ Depth +1.25 & $\mathrm{r}^{2}=0.947$ \\
$3-4 \mathrm{~cm}$ horizon & $\log$ Activity $=-0.000355$ Depth +1.12 & $\mathrm{r}^{2}=0.978$ \\
$9-10 \mathrm{~cm}$ horizon & $\log$ Activity $=-0.000666$ Depth +0.81 & $\mathrm{r}^{2}=0.648$ \\
\hline
\end{tabular}



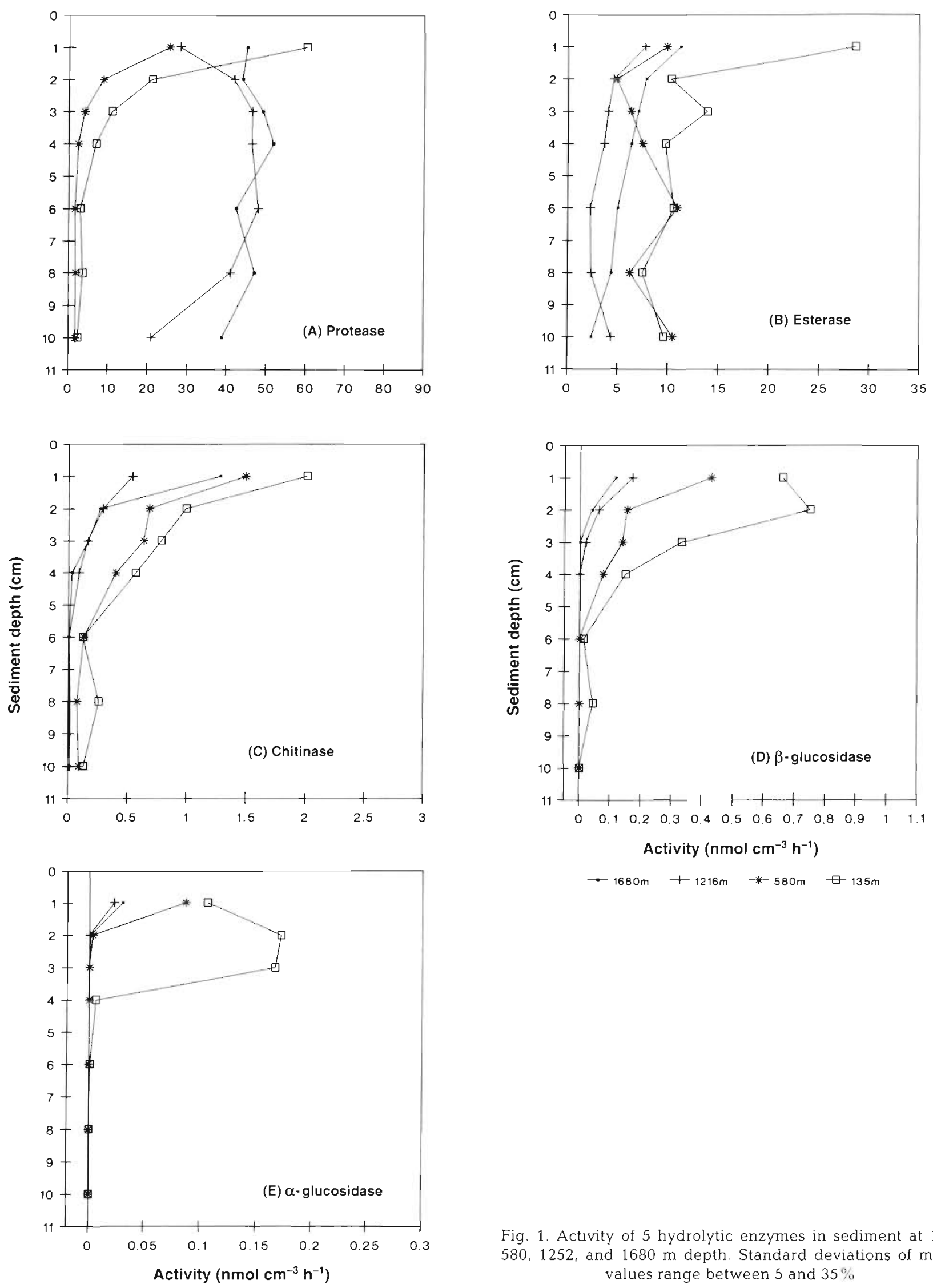

Fig. 1. Actuvity of 5 hydrolytic enzymes in sediment at 135 , 580,1252 , and $1680 \mathrm{~m}$ depth. Standard deviations of mean values range between 5 and $35 \%$ 
depths were not deep enough. A competitive advantage of barophilic bacteria is ex-pected at greater depths. (3) Depressurization could have destroyed barophilic bacteria, but this effect would be included in most experiments with deepsea bacteria reported so far. The first attempts with pressure-conserving sampling devices were reported by Jannasch et al. (1973), Wirsen \& Jannasch (1975), and Jannasch \& Wirsen (1982), but the picture concerning bacterial barophilism arising from these investigations was not really conclusive. In recent times, Bianchi \& Garcin (1993) used an improved device for the retrieval and incubation of deepwater samples without decompression. They demonstrated the existence of a pelagic barophilic microbial community at a relatively shallow water depth of $1100 \mathrm{~m}$ in the Mediterranean Sea.

Similar to the TdR uptake rates, most of the hydrolytic enzyme activities in the sediments decreased in the vertical profiles of the cores (Fig. $1 \mathrm{~A}$ to $\mathrm{E}$ ) and with increasing depth of the sampled station (Fig. 2). Time series measurements were significantly linear $(95 \%$ confidence level) nearly always in upper levels of sediment. Irregular profiles with lower activity at the sediment surface compared to deeper layers were obtained for the protease at the 2 deep stations (Fig. 1A), for the esterase at the $580 \mathrm{~m}$ station (Fig. 1B), and for both glucosidase profiles at the $135 \mathrm{~m}$ station (Fig. 1D, E). It is not very likely that bioturbation caused these profiles, because a simple transportation of organic material into deeper sediment layers would most probably produce irregular profiles of all enzymes. It is more likely that the irregular profiles were caused by a local occurrence of specific organic compounds, e.g. protein or starch, in subsurface layers Microbial metabolism is known for its high adaptivity.

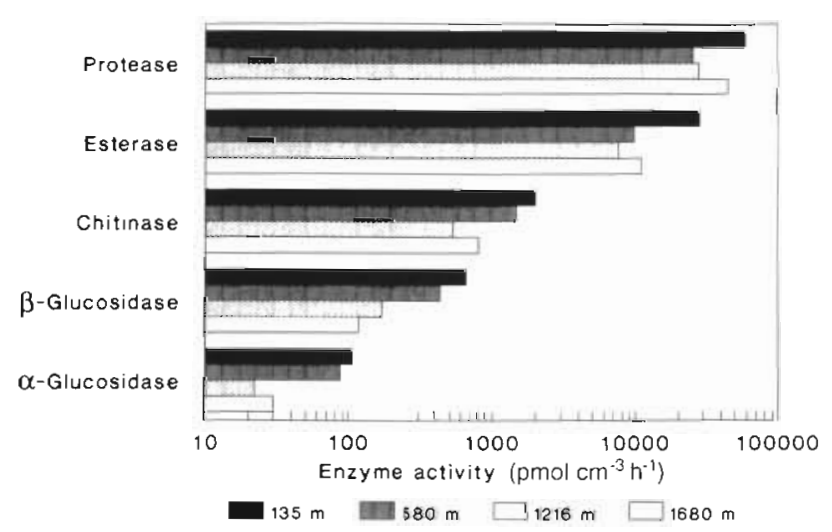

Fig. 2. Activity of 5 hydrolytic enzymes in the $0-1 \mathrm{~cm}$ sediment horizon of $\operatorname{Stns} 3,4,8$, and 10
Recent observations have shown that addition of organic materials can stimulate the activity of corresponding hydrolytic enzymes in coastal sediments (Meyer-Reil 1983) or sediments of the deep sea (Graf 1989, Boetius \& Lochte 1994). Supplementing sediment slurries with various amounts of particulate and dissolved organic matter, Boetius \& Lochte (1994) found enzyme induction for chitobiase and $\beta$-glucosidase, inhibition for aminopeptidase, but no effect on $\alpha$-glucosidase and lipase.

The ranking order of the mean enzyme activity rates in the sediment was protease $>$ esterase $>$ chitinase $>$ $\beta$-glucosidase $>\alpha$-glucosidase, which is similar to the ranking found in the deep NE Atlantic (Boetius 1994). The ratio between the activities generally increased with water depth, e.g. the ratio between the activity rates of protease and $\beta$-glucosidase shifted from 91 at the $135 \mathrm{~m}$ station to 567 at the $1680 \mathrm{~m}$ station.

Consequences of substrate input into the sediment are most obviously documented by changes of microbial activity in the uppermost layer of the sediment. Therefore we compared hydrolytic activities in the $0-1 \mathrm{~cm}$ layer of the sediments at the different stations down the continental slope in order to define depth relations of these parameters (Fig. 2). It can be seen that there is a more or less constant decrease of activities from the shallowest station down to $1216 \mathrm{~m}$. This decrease is continued only by $\beta$-glucosidase down to $1680 \mathrm{~m}$, while the other enzymes show an increase at this station. Regression analysis revealed a decrease of activities for all the enzymes over the transect, but this was only significant at a $95 \%$ confidence level for $\beta$-glucosidase ( $n=4, r^{2}=0.988$ ), and close to significant for $\alpha$-glucosidase ( $n=4, r^{2}=0.779$ ) (Table 4). The slopes of regression lines for $\alpha$ - and $\beta$-glucosidase $(-0.000509$ and -0.000438 , respectively $)$ are similar to those of thymidine incorporation and also to Alongi's (1990) equation mentioned above.

For the interpretation of our findings it has to be kept in mind that we measured hydrolytic potentials rather than actual substrate decomposition. Interpretation could be based on bacterial population characteristics, and/or substrate availability at the sea floor. In the case of protein degradation we anticipate that 
most bacteria are proteolytic because of the metabolic importance of proteins. At least for bacteria growing on agar plates it has been shown that nearly $100 \%$ of them are potentially proteolytic (Kim \& Hoppe 1986). Because no significant change in bacterial abundance with increasing water depth was recorded, no drastic change in protease activity should be expected. Actual proteolysis may be lower at greater depth.

Also, esterase activity (as measured by FDA hydrolysis) is most probably a property of all bacteria (Schnürer \& Rosswall 1982). It reflects the general metabolic potential of bacteria and it is sensu strictu not an extracellular enzymatic property. Esterase activity (also on an activity per cell basis) is elevated at the shallowest station, but there is no significant difference between the 3 deeper stations. Probably our stations were not deep enough to exhibit strong (and methodically detectable) changes in general metabolic potentials.

For the remaining activities (chitinase, $\alpha$-glucosidase, $\beta$-glucosidase) we anticipate a more specific substrate dependency. Degradation of chitin and carbohydrates is a matter of specialized bacteria, which make up only a portion of the total bacterial population. Abundances of these specialists should depend mostly on the availability of their specific substrates. Substrate availability in sediments is a function of degradation in the water column and POC production in the euphotic zone (e.g. Knauer \& Martin 1981, Suess 1988). Increasing water depth prolongs the residence time of sedimenting POM in the water column which favours the degradation of labile compounds. Increasing distance from land generally correlates with POC production in the epipelagic zone and supply of sedimenting organic matter to the underlying sediment. Both factors could regulate the abundance and activity of specialized bacteria in the manner shown by our results. Indications of such regulation of bacterial populations by substrate supply in batch experiments were reported by Boetius \& Lochte (1994).

Our results reflect the response of some bacterial properties to increasing depth at the slope of Goban Spur. Increasing water depth includes many factors, such as decreasing temperature, substrate availability, and substrate degradability in the sediment sphere. We are not able to decide about the relative importance of these factors, but our results suggest that there are distinct shifts of sediment bacterial population characteristics within relatively short distances from the shelf down to deep-sea regions.

Acknowledgements. Thanks are due to the crew of the RV 'Valdivia' for their helpful support, and especially K. Jeskulke for skilful technical assistance. The manuscript benefited from comments by Robin Keir, Karin Lochte and 3 anonymous reviewers. This work was supported by grant MUF 03F0094B of the Bundesministerium für Forschung und Technik, Germany. This is BIOTRANS publication no. 38

\section{LITERATURE CITED}

Alongi, D. M. (1990). Bacterial growth rates, production and estimates of detrital carbon utilization in deep-sea sediments of the Solomon and Coral Seas. Deep Sea Res. 37 : $731-746$

Angel, M. V. (1984). Detrital organic fluxes through pelagic ecosystems. In: Fasham, M. J. R. (ed.) Flows of energy and materials in marine ecosystems: theory and practice. Plenum Press, New York, p. 475-516

Altenbach, A. V. (1992). Short term processes and patterns in the foraminiferal response to organic flux rates. Mar. Micropaleontol. 19: 119-129

Barnett, P. R. O., Watson, J., Conelly, D. (1984). A multiple corer for taking virtually undisturbed samples from shelf, bathyl and abyssal sediments. Oceanol. Acta 7: 399-408

Bianchi, A., Garcin, J (1993). In stratified waters the metabolic rate of deep-sea bacteria decreases with decompression. Deep Sea Res. 40: 1703-1710

Billen, G., Joiris, C., Meyer-Reil, L.-A., Lindebloom, H. (1990). Role of bacteria in the North Sea ecosystem. Neth. J. Sea Res. 26(2-4): 265-293

Billett, D. S. M., Lampitt, R. S., Rice, A. L., Mantoura, R. F. C. (1983). Seasonal sedimentation of phytodetritus to the deep-sea benthos. Nature 302: 520-522

Boetius, A. (1994). Microbial hydrolytic enzyme activities in deep-sea sediments. Helgoländer Meeresunters. 49 (in press)

Boetius, A., Lochte, K. (1994). Regulation of microbial enzymatic degradation of organic matter in deep-sea sediments. Mar. Ecol. Prog. Ser. 104: 299-307

Deuser, W. G., Ross, E. H. (1980). Seasonal change in the flux of organic carbon to the deep Sargasso Sea. Nature 322: $70-73$

Deuser, W. G., Ross, E. H., Anderson, R. F. (1981). Seasonality in the supply of sediment to the deep Sargasso Sea and implications for the rapid transfer of matter to the deep ocean. Deep Sea Res. 28A: 495-505

Ducklow, H. W. (1983). Production and fate of bacteria in the oceans. BioSci. 33: 494-501

Ducklow, H. W., Kirchman, D. L., Quinby, H. L., Carlson C. A., Dam, H. G. (1993). Stocks and dynamics of bacterioplankton carbon during the spring bloom in the eastern North Atlantic Ocean. Deep Sea Res. 40: 245-263

Gage, J. D., Tyler, P. A. (1991). Deep-sea biology. Cambridge University Press, Cambridge, p. 504

Gooday, A. J. (1988). A benthic foraminiferal response to the deposition of phytodetritus in the deep-sea. Nature 332: $70-73$

Graf, G. (1989). Benthic coupling in a deep-sea community Nature 341: 437-439

Honjo, S. (1982). Seasonality and incorporation of biogenuc and lithogenic particulate flux at the Panama basın. Science 218: $883-884$

Hoppe, H.-G. (1991). Microbial extracellular enzyme activity a new key parameter in aquatic ecology. In: Chróst, R. J (ed.) Microbial enzymes in aquatic environments. Springer-Verlag, New York, p. 60-79

Hoppe, H.-G., Ducklow, H., Karrasch, B. (1993). Evidence for dependency of bacterial growth om enzymatic hydrolysis 
of particulate organic matter in the mesopelagic ocean. Mar. Ecol. Prog. Ser. 93: 277-283

Jannasch, H. W., Wirsen, C. O. (1982). Microbial activities in undecompressed and decompressed deep-seawater samples. Appl. environ. Microbiol. 43: 1116-1124

Jannasch, H. W., Wirsen, C. O., Winget, C. L. (1973). A bacteriological pressure-retaining deep-sea sampler and culture vessel. Deep Sea Res. 20: 661-664

Kim, S. J., Hoppe, H.-G. (1986). Microbial extracellular enzyme detection on agar plates by means of methylumbelliferyl-substrates. In: GERBAM - Deuxième Colloque International de Bactériologie Marine, Actes de Colloque, 3. IFREMER, Brest, p. 175-181

Knauer, G. A., Martin, J. H. (1981). Primary production and carbon-nitrogen fluxes in the upper $1,500 \mathrm{~m}$ of the northeast Pacific. Limnol. Oceanogr. 26: 181-186

Lampitt, R. S. (1985). Evidence for the seasonal deposition of detritus to the deep-sea floor and its subsequent resuspension. Deep Sea Res. 32: 885-897

Lochte, K., Ducklow, H. W., Fasham, M. J. R., Stienen, C. (1993). Plankton succession and carbon cycling at $47^{\circ} \mathrm{N}$ $20^{\circ} \mathrm{W}$ during the JGOFS North Atlantic Bloom Experiment. Deep Sea Res. 40: 91-114

Meyer-Reil, L.-A. (1983). Benthic response to sedimentation events during autumn to spring at a shallow-water station in the Western Kiel Bight. II. Analysis of benthic populations. Mar. Ecol. Prog. Ser. 77: 247-256

Meyer-Reil, L.-A. (1986). Measurement of hydrolytic activity and incorporation of dissolved organic substrates by microorganisms in marine sediments. Mar. Ecol. Prog. Ser. 31: $143-149$

Meyer-Reil, L.-A. (1990). Microorganisms in marine sediments: considerations concerning activity measurements. Arch. Hydrobiol. Beih. 34: 1-6

Meyer-Reil, L.-A. (1993). Mikrobielle Besiedlung und Produktion. In: Meyer-Reil, L.-A., Köster, M. (eds.) Mikrobiologie des Meeresbodens. Gustav Fischer Verlag, Jena, p. $38-81$

Meyer-Reil, L.-A., Köster, M. (1992). Microbial life in pelagic sediments: the impact of environmental parameters on enzymatic degradation of organic material. Mar. Ecol. Prog. Ser. 81: 65-72

Moriarty, D. J. W. (1990). Techniques for estimating bacterial growth rates and production of biomass in aquatic environments. In: Bergan, T., Norris, J. R. (eds.) Methods in microbiology, Vol. 22. Academic Press, London, p. 211-234

Pfannkuche, O. (1993). Benthic response to the sedimentation of particulate organic matter at the BIOTRANS station, $47^{\circ} \mathrm{N}, 20^{\circ} \mathrm{W}$. Deep Sea Res. 40: 135-149

Poremba, K. (1994). Simulated degradation of phytodetritus in deep sea sediments. Mar. Ecol. Prog. Ser 105: 291-299

Poremba, K., Lochte, K., Rheinheimer, G. (1993). Mikrobielle Abundanz und Aktivität im Sediment und bodennahen Wasser. In: Pfannkuche, O., Rheinheimer, G., Thiel, H. (eds.) Biologischer Kohlenstofffluß in der bodennahen Wasserschicht des küstenfernen Ozeans. Ber. Inst. Meereskde Univ. Kiel 242: 100-130

Poremba, K., Eardley, D., Patching, J. W. (1994). Dynamics of

This article was presented by G. Rheinheimer (Senior

Editorial Advisor), Kiel, Germany microbial abundance and activity in deep-sea sediment of the Northeast Atlantic. Microbiol. Eur. 2: 22-25

Rice, A. L., Billett, D. S. M., Fry, J., John, A. W. G., Lampitt, R. S., Mantoura, R. F. C., Morris, R. J. (1986). Seasonal deposition of phytodetritus to the deep-sea floor Proc. $R$ Soc. Edinburgh 88B: 265-279

Riemann, B., Bjomsen, P. K., Newell, S., Fallon, R. (1987). Calculation of cell production of coastal marine bacteria based on measured incorporation of $\left[{ }^{3} \mathrm{H}\right]$ thymidine. Limnol. Oceanogr. 32: 471-475

Rowe, G., Staresinic, N. (1979). Sources of organic matter to the deep-sea benthos. Ambio Spec. Rep. 6: 19-24

Schnürer, J., Rosswall, T (1982). Fluorescein diacetate hydrolysis as a measure of total microbial activity in soil and litter. Appl. environ. Microbiol. 43: 1256-1261

Simon, M., Azam, F. (1989). Protein content and protein synthesis rates of planktonic marine bacteria. Mar. Ecol. Prog. Ser. 51: 201-213

Smith, D. C., Simon, M., Alldredge, A. L., Azam, F. (1992). Intense hydrolytic enzyme activity on marine aggregates and implications for rapid particle dissolution. Nature 359: $139-142$

Suess, E. (1988). Particulate organic carbon flux in the oceansurface productivity and oxygen utilization. Nature 288 $260-263$

Thiel, H., Lochte, K., Gooday, A. J., Hemleben, C., Mantoura, R. F. C., Patching, J. W., Pfannkuche, O., Riemann, F., Schriever, G. Turley, C. M. $(1988 / 89)$. Phytodetritus on the deep-sea floor in a central oceanic region of the Northeast Atlantic. Biol. Oceanogr. 6: 203-239

Thorn, P. M., Ventullo, R. M. (1988). Measurement of bacterial growth rates in subsurface sediments using the incorportation of tritiated thymidine into DNA. Microb. Ecol. 16: $3-16$

Turley, C. M., Lochte, K. (1990). Microbial response to the input of fresh detritus to the deep-sea bed. In: Labeyrie, L. D., Jeandel, C. (eds.) Geochemical variability in the oceans, ice and sediments. Paleogeogr. Paleoclimatol. Paleoecol. (Global and Planetary Change Section) 89: $3-23$

Turley, C. M., Lochte, K., Patterson, D. J. (1988). A barophilic flagellate isolated from $4500 \mathrm{~m}$ in the mid-North Atlantic. Deep Sea Res. 35: 1079-1092

Walsh, J. J., Rowe, G. T., Iverson, R. L., McRoy, C. P. (1981). Biological export of shelf carbon is a sink of global $\mathrm{CO}_{2}$ cycle. Nature 291: 196-201

Wefer, G. (1989). Particle flux in the ocean: effects of episodic production. In: Berger, W. H., Smetacek, V., Wefer, G. (eds.) Productivity of the ocean: present and past. John Wiley \& Sons, New York, p. 139-154

Williams, P. J. leB. (1981). Incorporation of microheterotrophic processes into the classical paradigm of the planktonic food web. Kieler Meeresforsch. 5: 1-28

Wirsen, C. O., Jannasch, H. W. (1975). Activity of marine psychrophilic bacteria at elevated hydrostatic pressures and low temperatures. Mar. Biol. 31: 201-208

Zimmermann, R., Meyer-Reil, L.-A. (1974). A new method for fluorescence staining of bacterial populations on membrane filters. Kieler Meeresforsch. 30: 24-27

Manuscript first received: April 15, 1994

Revised version accepted: December 19, 1994 